\title{
Correction to: A statistical analysis of geomechanical data and its effect on rock mass numerical modeling: a case study
}

Piotr Małkowski ${ }^{1}$ (1) $\cdot$ Zbigniew Niedbalski $^{1} \cdot$ Tafida Balarabe $^{2}$

Published online: 22 November 2020

(C) The Author(s) 2020, corrected publication 2020

\section{Correction to:}

Int J Coal Sci Technol

https://doi.org/10.1007/s40789-020-00369-2

In the original publication the resolution of Figures 1 and 2 need improvement. The correct version of figures is available in this correction. The original article has been corrected.

The original article can be found online at https://doi.org/10.1007/ s40789-020-00369-2.

Piotr Małkowski

malkgeom@agh.edu.pl

1 Faculty of Mining and Geoengineering, AGH University of Science and Technology, al. Mickiewicza 30, 30-059 Kraków, Poland

2 Revoult Ltd, al. Jana Pawła II 43a, 31-864 Kraków, Poland 


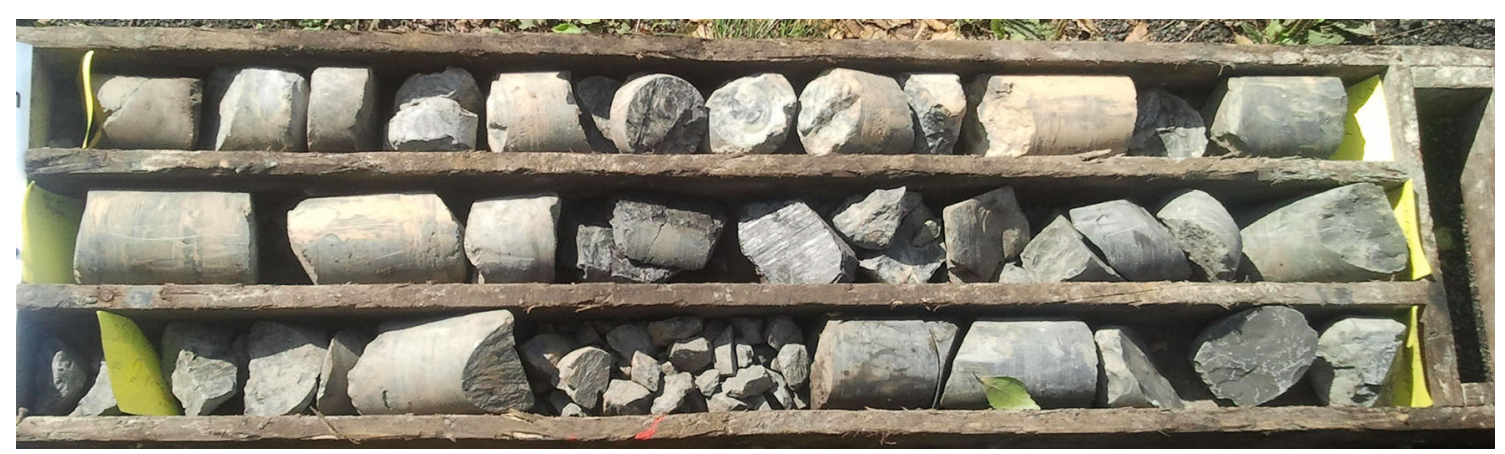

Fig. 1 Intensely crushed core from the floor of the work site

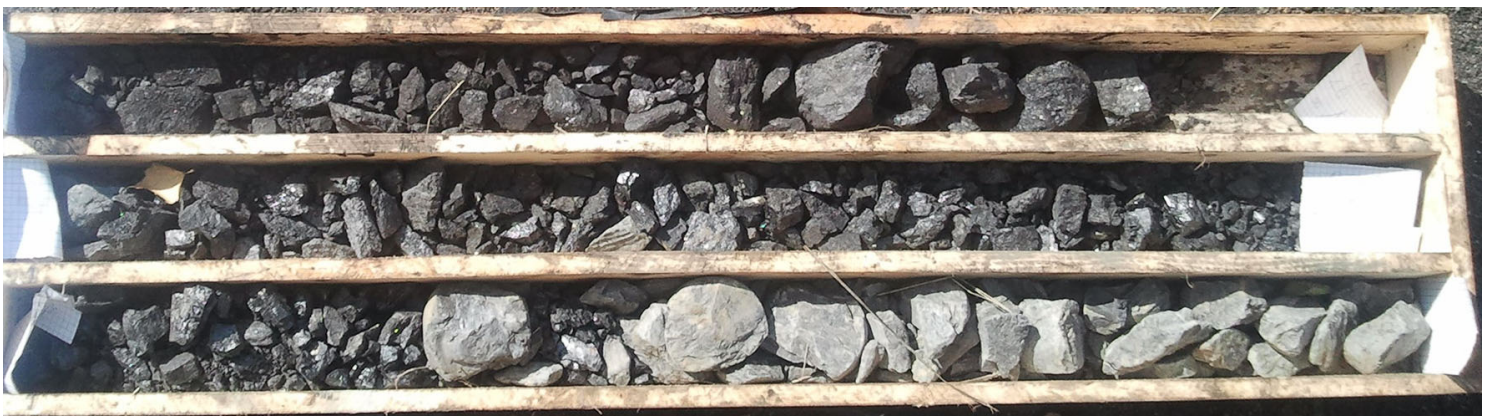

Fig. 2 Entirely crushed core from the floor of the work site

Open Access This article is licensed under a Creative Commons Attribution 4.0 International License, which permits use, sharing, adaptation, distribution and reproduction in any medium or format, as long as you give appropriate credit to the original author(s) and the source, provide a link to the Creative Commons licence, and indicate if changes were made. The images or other third party material in this article are included in the article's Creative Commons licence, unless indicated otherwise in a credit line to the material. If material is not included in the article's Creative Commons licence and your intended use is not permitted by statutory regulation or exceeds the permitted use, you will need to obtain permission directly from the copyright holder. To view a copy of this licence, visit http://creativecommons. org/licenses/by/4.0/. 